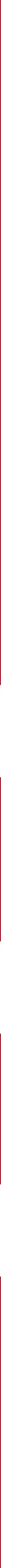




\title{
Wildfires in Poland: the impact of risk preferences and loss aversion on environmental choices
}

\author{
ANNA BARTCZAK \\ Faculty of Economic Sciences, \\ Warsaw Ecological Economics Center \\ University of Warsaw \\ e-mail: bartczak@wne.uw.edu.pl
}

\author{
Susan Chilton \\ Newcastle University \\ Business School
}

\author{
JÜRGEN MEYERHOFF \\ Technische Universität Berlin, \\ Institute for Landscape and Environmental Planning
}

\begin{abstract}
This paper examines how risk preferences and loss aversion affect choices over a risky environmental good, wildfire prevention in Poland. We collect data in a stated preference survey that allows us to calculate both risk aversion and loss aversion parameters from individual respondents in both the financial and environmental domains. In doing so, we are able to confirm that this behaviour is consistent with prospect theory and holds for the majority of respondents. Additionally, we find little evidence of domain specificity of risk: responses to the financial risk questions were good predictors of responses to the environmental risk questions.
\end{abstract}

Keywords:

risk preferences over financial and environmental domains, forest fires, loss aversion, probability weighting, prospect theory

JEL:

Q51, D03, D81

\section{Acknowledgments:}

This study was carried out as a part of "The influence of risk preferences on social benefits valuation for forest fires prevention in Poland" financed by National Science Centre Poland (OPUS I, project no. 152274). Funding support is gratefully acknowledged. 


\section{Introduction}

One area of non-market valuation which raises some fundamental questions both in terms of respondent cognition and subsequent analysis and interpretation is that of risky environmental goods. Whilst there is a growing body of evidence with respect to peoples' preferences over such goods - for example, focussing on outcome uncertainty (Richardson and Loomis, 2009 or supply uncertainty (Rigby et al., 2011; Rolfe and Windle, 2010; Glenk and Columbo, 2011) - it is nevertheless the case that much remains to be discovered. It is an open question as to whether peoples' choices are driven primarily by risk attitudes to the environment, to finance or to some combination of both but the more pressing question is to identify the most appropriate behavioural model to guide analysis and ultimately improve the predictive powers of our willingness-to-pay (WTP) models.

Standard economic analytical techniques assume Expected Utility Theory (EUT) as the underlying model when estimating WTP. If this assumption is inappropriate for risky environmental decisions, WTP will be underestimated (see Riddell, 2012). A number of psychological studies, in particular Weber et al. (2002), provide strong evidence to the effect that risk preferences are domain specific, but this only goes part of the way in explaining how respondents' choices may be influenced by their fundamental risk preferences.

Against this background, Riddell (2012) provided a framework within which to capture environmental risk preferences in such a way that allows environmental choices to be elicited, interpreted and analysed in exactly the same way as risky financial choices. By eliciting a probability weighting function as well as a risk preference function she was also able to establish that prospect theory was a better descriptor of behaviour than EUT. In this paper, we replicate her analysis in both contexts but extend it to consider the third parameter of prospect theory, namely loss aversion. We apply Tanaka et al. (2010) procedures in the context of financial risks but then adapt them to provide, for the first time, evidence in respect of environmental loss aversion, in our case in the context of wildfire risk reduction in Poland.

Specifically, by capturing both risk aversion and loss aversion parameters from individual respondents we are able to examine the value function in its entirety. We confirm that behaviour is consistent with prospect theory in both the cases of environmental gains and environmental losses. We also provide additional evidence on the transferability of risk preferences over finance to other domains, in this case finding no strong evidence of domain specificity.

The remainder of the paper is as follows. Section 2 details the theoretical specifications and empirical methods used to define and elicit the relevant parameters. Section 3 gives brief details of the survey and sample characteristics whilst Section 4 contains the results of our analysis. Section 5 discusses these results and offers some observations on their implications for future stated preference survey design.

\section{Theoretical considerations}

We consider Prospect Theory (PT) (Kahneman and Tversky, 1979) as an alternative to EUT in the domains of gains and losses. In PT the shape of the utility function is jointly determined by risk aversion, loss aversion and nonlinear probability weighting. 
Following Tanaka et al. (2010) we assume the one-parameter form of Prelec's (1998) axiomatically derived weighting function.

Assuming a piece-wise power function for $v(x)$, the value function can be written:

$$
v(x)=\left\{\begin{array}{c}
x^{1-\sigma} \text { if } x \geq 0 \\
-\lambda(-x)^{1-\sigma} \text { if } x<0
\end{array}\right.
$$

where $x$ is an outcome, $\sigma$ represents concavity of the value function and $\lambda$ is the degree of loss aversion. If an individual is risk loving then $\sigma<0$, if she is risk neutral then $\sigma=0$, and risk averse if $\sigma>0$.

The loss aversion parameter $\lambda$ measures one's sensitivity to loss compared to gain. In PT, gains and losses are compared to a reference point (the current position) and can accommodate different weightings - specifically that losses are weighted more heavily than equivalent gains. A probability weighting function considered in the current study is 1 :

$$
\pi(p)=\frac{1}{\exp \left[\ln \left(\frac{1}{p}\right)\right]^{\alpha}}
$$

where $p$ is the probability of the outcome $\mathrm{x}$ and $\alpha$ is the probability sensitivity parameter.

If $\alpha<1$, the weighting function is inverted S-shaped, i.e. individuals overweight small probabilities and underweight large probabilities (Tversky and Kahneman, 1992) and hence are probabilistic risk averse for low likelihood losses and high likelihood gains and, conversely, probabilistic risk seeking for low likelihood gains and high likelihood losses. If $\alpha>1$ then the weighting function is S-shaped. In both of these cases, preferences are non-linear.

By contrast, if preferences are linear and probability weighting is absent, the probability sensitivity parameter $\alpha$ equals 1 , as the loss aversion parameter (i.e. $\lambda=1$ ) and EUT applies. ${ }^{2}$

The PT utility function for a two outcome gamble can be written as:

$U(x, p ; y, q)= \begin{cases}\pi(p) v(x)+(1-\pi(p)) v(y) & \text { if } x>y>0 \text { or } x<y<0 \\ \pi(p) v(x)+\pi(q) v(y) & \text { if } x<0<y\end{cases}$

where: $x$ and $y$ are the outcomes, and $p$ and $q$ are probabilities associated with those outcomes.

\footnotetext{
1 This process of transforming the probabilities into decision weights breaks the independence axiom i.e. probabilities and outcomes are independent (Starmer, 2000).

2 In EUT the utility function is linear in $p$ i.e. $E U(x ; p)=\sum_{i} p_{i} v\left(x_{i}\right)$.
} 
Table 1. Values of EUT and PT parameters.

\begin{tabular}{|c|c|c|c|c|c|}
\hline \multirow{2}{*}{ Function } & \multirow{2}{*}{ Parameters } & \multicolumn{4}{|c|}{ Theory } \\
\hline & & & cted Utility* & & Prospect \\
\hline $\begin{array}{l}\text { Weighting } \\
\text { function }\end{array}$ & $\begin{array}{l}\text { Probability } \\
\text { sensitivity } \\
\text { parameter }\end{array}$ & $\alpha=1$ & $\begin{array}{c}\text { Probability } \\
\text { weighting is } \\
\text { absent }\end{array}$ & $\alpha<1$ & $\begin{array}{c}\text { small } \\
\text { probabilities \& } \\
\text { underweight } \\
\text { large } \\
\text { probabilities }\end{array}$ \\
\hline $\begin{array}{l}\text { Value } \\
\text { function }\end{array}$ & $\begin{array}{c}\text { Loss } \\
\text { aversion } \\
\text { parameter }\end{array}$ & $\lambda=1$ & $\begin{array}{c}\text { Losses are } \\
\text { weighted the } \\
\text { same as gains }\end{array}$ & $\lambda>1$ & $\begin{array}{c}\text { Losses are } \\
\text { weighed more } \\
\text { heavily than } \\
\text { gains }\end{array}$ \\
\hline
\end{tabular}

Note: * Assuming a standard EU functional form.

\section{Method}

Individual willingness to take risk cannot be straightforwardly measured and because of that, in the past decades a wide set of instruments has been developed to elicit risk attitudes (see e.g. Weber and Johnson, 2008). Two main approaches for the risk elicitation can be distinguish. The first one allows to infer risk preferences based on individuals actual choices in real or hypothetical games (e.g. Binswanger 1980, Holt and Laury, 2002 or Tanaka, 2010). A major advantage of this approach, is that it allows to rank risk preferences and identify groups risk seekers risk lovers, risk-neutral people. The other approach aims to elicit risk attitudes by asking individuals about their engagement in their daily life risky situations (e.g. Jackson et al., 1972 or Weber et al, 2002).

In this section we first outline Tanaka et al.'s (2010) experimental lotteries design adapted for the purpose of our study. The advantage of this design is that it allows to estimate empirical specifications that nest both EUT and PT. Based on the experiment results it is possible to determine whether EUT or PT better fits the data. Tanaka et al.'s (2010) extended multiple price list (MPL) approach has been tested inter alia by Riddel (2012) and Liu (2013). In the second part of this section we describe an alternative risk attitude elicitation device - Domain Specific Risk Talking scale (DOSPERT) developed by Weber et al. (2002). The DOSPERT domains scores have been shown to be associated with real-life risk taking activities inter alia by Hanoch et al. (2006). Applying those two approaches allows for psychological validation of financial and environmental risk measures and the derived parameters.

\subsection{Elicitation of probability weighting and loss aversion parameters}

To capture risk preferences in the financial and environmental domains we apply Tanaka et al.'s (2010) MPL design. In this approach, individuals are presented with three series of lottery pairs and asked to choose one lottery for each pair. When moving down the list of lotteries, payoffs in Option B increase while everything else is fixed. The 
choices are designed so that any combination of choices in the three series determines a particular interval of prospect theory parameter values (see Table 2 ). ${ }^{3}$

Table 2. Three series of pairwise lottery choices for the financial outcome domain.

\begin{tabular}{|c|c|c|c|c|c|c|c|c|}
\hline \multicolumn{9}{|c|}{ Series 1} \\
\hline \multicolumn{4}{|c|}{ Option A } & \multicolumn{4}{|c|}{ Option B } & \multirow{2}{*}{$\begin{array}{l}\mathrm{EV}(\mathrm{A})- \\
\mathrm{EV}(\mathrm{B})\end{array}$} \\
\hline Prob. & Payoff & Prob. & Payoff & Prob. & Payoff & Prob. & Payoff & \\
\hline 0.3 & $400 \mathrm{zf}$ & 0.7 & $100 \mathrm{zł}$ & 0.1 & $680 \mathrm{zł}$ & 0.9 & $50 \mathrm{zł}$ & $77 \mathrm{zf}$ \\
\hline 0.3 & $400 \mathrm{zł}$ & 0.7 & $100 \mathrm{zł}$ & 0.1 & 750 zł & 0.9 & $50 \mathrm{zt}$ & $70 \mathrm{zt}$ \\
\hline 0.3 & $400 \mathrm{zł}$ & 0.7 & $100 \mathrm{zł}$ & 0.1 & $830 \mathrm{zł}$ & 0.9 & $50 \mathrm{zt}$ & $62 \mathrm{zt}$ \\
\hline 0.3 & $400 \mathrm{zł}$ & 0.7 & $100 \mathrm{zł}$ & 0.1 & $930 \mathrm{zł}$ & 0.9 & $50 \mathrm{zt}$ & $52 \mathrm{zt}$ \\
\hline 0.3 & $400 \mathrm{zł}$ & 0.7 & $100 \mathrm{zł}$ & 0.1 & $1060 \mathrm{zt}$ & 0.9 & $50 \mathrm{zt}$ & $39 \mathrm{zt}$ \\
\hline 0.3 & $400 \mathrm{zł}$ & 0.7 & $100 \mathrm{zt}$ & 0.1 & $1250 \mathrm{zt}$ & 0.9 & $50 \mathrm{zt}$ & $20 \mathrm{zt}$ \\
\hline 0.3 & $400 \mathrm{zł}$ & 0.7 & $100 \mathrm{zł}$ & 0.1 & $1500 \mathrm{zt}$ & 0.9 & $50 \mathrm{zt}$ & $-5 \mathrm{zł}$ \\
\hline 0.3 & $400 \mathrm{zł}$ & 0.7 & $100 \mathrm{zł}$ & 0.1 & $1850 \mathrm{zt}$ & 0.9 & $50 \mathrm{zł}$ & $-40 \mathrm{zł}$ \\
\hline 0.3 & $400 \mathrm{zł}$ & 0.7 & $100 \mathrm{zł}$ & 0.1 & $2200 \mathrm{zt}$ & 0.9 & $50 \mathrm{zł}$ & $-75 \mathrm{zł}$ \\
\hline 0.3 & $400 \mathrm{zł}$ & 0.7 & $100 \mathrm{zt}$ & 0.1 & $3000 \mathrm{zt}$ & 0.9 & $50 \mathrm{zt}$ & $-155 \mathrm{zł}$ \\
\hline 0.3 & $400 \mathrm{zł}$ & 0.7 & $100 \mathrm{z} \nmid$ & 0.1 & $4000 \mathrm{zt}$ & 0.9 & $50 \mathrm{zł}$ & $-255 \mathrm{zt}$ \\
\hline 0.3 & $400 \mathrm{zł}$ & 0.7 & $100 \mathrm{zt}$ & 0.1 & $6000 \mathrm{zt}$ & 0.9 & $50 \mathrm{zł}$ & $-455 \mathrm{zt}$ \\
\hline 0.3 & $400 \mathrm{zł}$ & 0.7 & $100 \mathrm{zt}$ & 0.1 & $10000 \mathrm{zł}$ & 0.9 & $50 \mathrm{zt}$ & $-855 \mathrm{zł}$ \\
\hline 0.3 & $400 \mathrm{zf}$ & 0.7 & $100 \mathrm{zł}$ & 0.1 & $17000 \mathrm{zt}$ & 0.9 & $50 \mathrm{z} \nmid$ & $-1555 \mathrm{zt}$ \\
\hline \multicolumn{9}{|c|}{ Series 2} \\
\hline \multicolumn{4}{|c|}{ Option A } & \multicolumn{4}{|c|}{ Option B } & $\begin{array}{l}\mathrm{EV}(\mathrm{A})- \\
\mathrm{EV}(\mathrm{B})\end{array}$ \\
\hline Prob. & Payoff & Prob. & Payoff & Prob. & Payoff & Prob. & Payoff & \\
\hline 0.9 & $400 \mathrm{zf}$ & 0.1 & $300 \mathrm{zf}$ & 0.7 & $540 \mathrm{zł}$ & 0.3 & $50 \mathrm{zł}$ & $-3 \mathrm{zt}$ \\
\hline 0.9 & $400 \mathrm{zł}$ & 0.1 & $300 \mathrm{zł}$ & 0.7 & $560 \mathrm{zł}$ & 0.3 & $50 \mathrm{zt}$ & $-17 \mathrm{zł}$ \\
\hline 0.9 & $400 \mathrm{zł}$ & 0.1 & $300 \mathrm{zł}$ & 0.7 & $580 \mathrm{zł}$ & 0.3 & $50 \mathrm{zt}$ & $-31 \mathrm{zł}$ \\
\hline 0.9 & $400 \mathrm{zł}$ & 0.1 & $300 \mathrm{zł}$ & 0.7 & $600 \mathrm{zł}$ & 0.3 & $50 \mathrm{zt}$ & $-45 \mathrm{zt}$ \\
\hline 0.9 & $400 \mathrm{zł}$ & 0.1 & $300 \mathrm{zł}$ & 0.7 & $620 \mathrm{zt}$ & 0.3 & $50 \mathrm{zt}$ & $-59 \mathrm{zł}$ \\
\hline 0.9 & $400 \mathrm{zł}$ & 0.1 & $300 \mathrm{zł}$ & 0.7 & $650 \mathrm{zł}$ & 0.3 & $50 \mathrm{zt}$ & $-80 \mathrm{zt}$ \\
\hline 0.9 & $400 \mathrm{zł}$ & 0.1 & $300 \mathrm{zf}$ & 0.7 & $680 \mathrm{zł}$ & 0.3 & $50 \mathrm{zt}$ & $-101 \mathrm{zł}$ \\
\hline 0.9 & $400 \mathrm{zł}$ & 0.1 & $300 \mathrm{zł}$ & 0.7 & $720 \mathrm{zł}$ & 0.3 & $50 \mathrm{zł}$ & $-129 \mathrm{z \dagger}$ \\
\hline 0.9 & $400 \mathrm{zf}$ & 0.1 & $300 \mathrm{zł}$ & 0.7 & $770 \mathrm{zł}$ & 0.3 & $50 \mathrm{zł}$ & $-164 z \nmid$ \\
\hline 0.9 & $400 \mathrm{zł}$ & 0.1 & $300 \mathrm{zł}$ & 0.7 & $830 \mathrm{zł}$ & 0.3 & $50 \mathrm{zt}$ & $-206 \mathrm{zł}$ \\
\hline 0.9 & $400 \mathrm{z} \dagger$ & 0.1 & $300 \mathrm{zt}$ & 0.7 & $900 \mathrm{zł}$ & 0.3 & $50 \mathrm{zt}$ & $-255 z \nmid$ \\
\hline 0.9 & $400 \mathrm{zł}$ & 0.1 & $300 \mathrm{zł}$ & 0.7 & $1000 \mathrm{zt}$ & 0.3 & $50 \mathrm{zł}$ & $-325 \mathrm{zf}$ \\
\hline 0.9 & $400 \mathrm{zł}$ & 0.1 & $300 \mathrm{zł}$ & 0.7 & $1100 \mathrm{zt}$ & 0.3 & $50 \mathrm{zt}$ & $-395 \mathrm{zł}$ \\
\hline 0.9 & $400 \mathrm{zf}$ & 0.1 & $300 \mathrm{zł}$ & 0.7 & $1300 \mathrm{zt}$ & 0.3 & $50 \mathrm{zt}$ & $-535 \mathrm{zf}$ \\
\hline \multicolumn{9}{|c|}{ Series 3} \\
\hline \multicolumn{4}{|c|}{ Option A } & \multicolumn{4}{|c|}{ Option B } & $\begin{array}{l}\text { EV(A)- } \\
\text { EV(B) }\end{array}$ \\
\hline Prob. & Payoffs & Prob. & Payoffs & Prob. & Payoffs & Prob. & Payoffs & \\
\hline 0.5 & $250 \mathrm{zf}$ & 0.5 & -40 zł & 0.5 & $300 \mathrm{zt}$ & 0.5 & $-210 \mathrm{zł}$ & $60 \mathrm{zt}$ \\
\hline 0.5 & $40 \mathrm{z} \nmid$ & 0.5 & $-40 z \nmid$ & 0.5 & $300 \mathrm{zł}$ & 0.5 & $-210 \mathrm{z} \nmid$ & $-45 z \nmid$ \\
\hline 0.5 & $10 \mathrm{zt}$ & 0.5 & $-40 \mathrm{zł}$ & 0.5 & $300 \mathrm{zt}$ & 0.5 & $-210 \mathrm{z \nmid}$ & $-60 \mathrm{zt}$ \\
\hline
\end{tabular}

3 The standard MPL approach assumes underlying EUT behavior in the lottery choices (see e.g. Binswanger, 1980 or Holt and Laury, 2002). 


\begin{tabular}{|c|c|c|c|c|c|c|c|c|}
\hline 0.5 & $10 \mathrm{z \nmid}$ & 0.5 & $-40 \mathrm{zł}$ & 0.5 & $300 \mathrm{zł}$ & 0.5 & $-160 \mathrm{z \nmid}$ & $-85 \mathrm{zt}$ \\
\hline 0.5 & $10 \mathrm{z} \nmid$ & 0.5 & $-80 \mathrm{zł}$ & 0.5 & $300 \mathrm{zt}$ & 0.5 & $-160 \mathrm{z} \nmid$ & $-105 \mathrm{zł}$ \\
\hline 0.5 & $10 \mathrm{zt}$ & 0.5 & $-80 \mathrm{zł}$ & 0.5 & $300 \mathrm{zt}$ & 0.5 & $-140 \mathrm{z} \nmid$ & $-115 \mathrm{zł}$ \\
\hline 0.5 & $10 \mathrm{zt}$ & 0.5 & $-80 \mathrm{zł}$ & 0.5 & $300 \mathrm{zt}$ & 0.5 & $-110 \mathrm{z} \nmid$ & $-130 \mathrm{zt}$ \\
\hline
\end{tabular}

The switching points in Series 1 and 2 jointly determine the parameter for the curvature of the value function $(\sigma)$ and the probability weighting parameter $(\alpha)$. In Series 1 when an individual switches from Option $A$ at row $N$ it means that she prefers Option A over Option B at N-1 rows and prefers Option B over Option A at row N (and following rows) ${ }^{4}$. The same approach is used in Series 2 (rows notation K-1 and K). To determine ranges for both parameters the following inequalities should be satisfied:

$$
\left\{\begin{array}{c}
\left(x_{S 1, A, N-1}\right)^{\sigma} \exp \left[-\left(-\ln \left(p_{S 1, N-1}\right)\right)^{\alpha}\right]+\left(y_{B, N-1}\right)^{\sigma}\left\{1-\exp \left[-\left(-\ln \left(p_{S 1, N-1}\right)\right)^{\alpha}\right]\right\}> \\
\left(x_{S 1, B, N-1}\right)^{\sigma} \exp \left[-\left(-\ln \left(q_{S 1, N-1}\right)\right)^{\alpha}+\left(y_{S 1, A, N-1}\right)^{\sigma}\left\{1-\exp \left[-\left(-\ln \left(q_{S 1, N-1}\right)\right)^{\alpha}\right]\right\}\right. \\
\left(x_{S 1, B, N}\right)^{\sigma} \exp \left[-\left(-\ln \left(p_{S 1, N}\right)\right)^{\alpha}\right]+\left(y_{A, N}\right)^{\sigma}\left\{1-\exp \left[-\left(-\ln \left(p_{S 1, N}\right)\right)^{\alpha}\right]\right\}> \\
\left(x_{S 1, A, N}\right)^{\sigma} \exp \left[-\left(-\ln \left(q_{S 1, N}\right)\right)^{\alpha}+\left(y_{S 1, B, N}\right)^{\sigma}\left\{1-\exp \left[-\left(-\ln \left(q_{S 1, N}\right)\right)^{\alpha}\right]\right\}\right. \\
\left(x_{S 2, A, K-1}\right)^{\sigma} \exp \left[-\left(-\ln \left(p_{S 2, K-1}\right)\right)^{\alpha}\right]+\left(y_{B, K-1}\right)^{\sigma}\left\{1-\exp \left[-\left(-\ln \left(p_{S 2, K-1}\right)\right)^{\alpha}\right]\right\}> \\
\left(x_{S 2, B, K-1}\right)^{\sigma} \exp \left[-\left(-\ln \left(q_{S 2, K-1}\right)\right)^{\alpha}+\left(y_{S 2, A, K-1}\right)^{\sigma}\left\{1-\exp \left[-\left(-\ln \left(q_{S 2, K-1}\right)\right)^{\alpha}\right]\right\}\right. \\
\left(x_{S 2, B, K}\right)^{\sigma} \exp \left[-\left(-\ln \left(p_{S 2, K}\right)\right)^{\alpha}\right]+\left(y_{A, K}\right)^{\sigma}\left\{1-\exp \left[-\left(-\ln \left(p_{S 2, K}\right)\right)^{\alpha}\right]\right\}> \\
\left(x_{S 2, A, K}\right)^{\sigma} \exp \left[-\left(-\ln \left(q_{S 2, K}\right)\right)^{\alpha}+\left(y_{S 2, B, K}\right)^{\sigma}\left\{1-\exp \left[-\left(-\ln \left(q_{S 2, K}\right)\right)^{\alpha}\right]\right\}\right.
\end{array}\right.
$$

where $\mathrm{x}$ and $\mathrm{y}$ are outcomes, $p$ is the probability of the outcome $\mathrm{x}, \mathrm{N}$ and $\mathrm{K}$ denote the number of rows, A and B indicate the lottery options, and S1 and S2 denote Series 1 and Series 2, respectively. The pair of parameters $\alpha$ and $\sigma$ is not uniquely determinable. In this case we follow Tanaka et al. (2010) and their convention approximating $\alpha$ and $\sigma$ by taking the midpoint of the interval.

The loss aversion parameter can be determined by the switching points in Series 3 after obtaining an estimate of $\sigma$ based on individuals choices in Series 1 and Series 2 . Similar to $\alpha$ and $\sigma$, the loss aversion parameter $\lambda$ can also be estimated as the midpoint of an interval; a higher $\lambda$ represents a higher degree of loss aversion.

Following Riddel (2012), to capture risk preferences not only in the financial domain but also in the environmental domain, we established a set of corresponding hypothetical lotteries whose outcomes were reductions in the risk of forest wildfires in Poland. In addition to the lottery choices comparable to Riddel's survey, we also applied a third set of lotteries (Series 3) to explore individuals' loss aversion. This way, we frame our analysis in not only in gains and but also in losses domains.

\footnotetext{
${ }^{4}$ Similarly to Tanaka et al. (2010) we tried to enforce monotonic switching by asking respondents at which row they would switch from Option A to Option B in each series noting that they can also start to choose Option B with the first row. However, those who insisted to switch back were allowed to do so.
} 
In the environmental lottery tasks in Series 1 and Series 2 respondents were asked to make a choice between programs that, instead of financial rewards, presented them environmental effects of programs to reduce the risk of forest wildfires. They were told that there are two potential programs to further reduce the risk of forest fires in addition to the current fire protection management. However, the success rate of the two options is different. The results were described as the annual average reduction of burned forest area in Poland and were presented as uncertain (as they might depend on various factor earlier explained to the respondents). The respondents were asked to assume the costs of these programs were the same. Table 3 shows all presented environmental choice.

Table 3. Three series of pairwise lottery choices for the environmental outcome domain.

\begin{tabular}{|c|c|c|c|c|c|c|c|c|}
\hline \multicolumn{9}{|c|}{ Series 1} \\
\hline \multicolumn{4}{|c|}{ Program A } & \multicolumn{4}{|c|}{ Program B } & \multirow{2}{*}{$\begin{array}{l}\text { EV(A)- } \\
\text { EV(B) }\end{array}$} \\
\hline Prob. & $\begin{array}{l}\text { Saved } \\
\text { forest }\end{array}$ & Prob. & $\begin{array}{l}\text { Saved } \\
\text { forest }\end{array}$ & Prob. & $\begin{array}{l}\text { Saved } \\
\text { forest }\end{array}$ & Prob. & $\begin{array}{l}\text { Saved } \\
\text { forest }\end{array}$ & \\
\hline 0,3 & 100 ha & 0,7 & 25 ha & 0,1 & 170,0 ha & 0,9 & 12,5 ha & $19,3 \mathrm{ha}$ \\
\hline 0,3 & 100 ha & 0,7 & 25 ha & 0,1 & 187,5 ha & 0,9 & 12,5 ha & 17,5 ha \\
\hline 0,3 & 100 ha & 0,7 & 25 ha & 0,1 & 207,5 ha & 0,9 & 12,5 ha & 15,5 ha \\
\hline 0,3 & 100 ha & 0,7 & 25 ha & 0,1 & 232,5 ha & 0,9 & 12,5 ha & 13,0 ha \\
\hline 0,3 & 100 ha & 0,7 & 25 ha & 0,1 & 265,0 ha & 0,9 & 12,5 ha & 9,8 ha \\
\hline 0,3 & 100 ha & 0,7 & 25 ha & 0,1 & 312,5 ha & 0,9 & 12,5 ha & 5,0 ha \\
\hline 0,3 & 100 ha & 0,7 & 25 ha & 0,1 & 375,0 ha & 0,9 & 12,5 ha & $-1,3$ ha \\
\hline 0,3 & 100 ha & 0,7 & 25 ha & 0,1 & 462,5 ha & 0,9 & 12,5 ha & $-10,0$ ha \\
\hline 0,3 & 100 ha & 0,7 & 25 ha & 0,1 & 550,0 ha & 0,9 & 12,5 ha & $-18,8$ ha \\
\hline 0,3 & 100 ha & 0,7 & 25 ha & 0,1 & 750,0 ha & 0,9 & 12,5 ha & $-38,8$ ha \\
\hline 0,3 & 100 ha & 0,7 & 25 ha & 0,1 & 1000,0 ha & 0,9 & 12,5 ha & $-63,8$ ha \\
\hline 0,3 & 100 ha & 0,7 & 25 ha & 0,1 & 1500,0 ha & 0,9 & 12,5 ha & $-113,8$ ha \\
\hline 0,3 & 100 ha & 0,7 & 25 ha & 0,1 & 2500,0 ha & 0,9 & 12,5 ha & $-213,8$ ha \\
\hline 0,3 & 100 ha & 0,7 & 25 ha & 0,1 & 4250,0 ha & 0,9 & 12,5 ha & $-388,8$ ha \\
\hline \multicolumn{9}{|c|}{ Series 2} \\
\hline \multicolumn{4}{|c|}{ Program A } & \multicolumn{4}{|c|}{ Program B } & $\begin{array}{l}\mathrm{EV}(\mathrm{A})- \\
\mathrm{EV}(\mathrm{B})\end{array}$ \\
\hline Prob. & $\begin{array}{l}\text { Saved } \\
\text { forest }\end{array}$ & Prob. & $\begin{array}{l}\text { Saved } \\
\text { forest }\end{array}$ & Prob. & $\begin{array}{l}\text { Saved } \\
\text { forest }\end{array}$ & Prob. & $\begin{array}{l}\text { Saved } \\
\text { forest }\end{array}$ & \\
\hline 0,9 & 100 ha & 0,1 & 75 ha & 0,7 & 135,0 ha & 0,3 & 12,5 ha & $-0,8$ ha \\
\hline 0,9 & 100 ha & 0,1 & 75 ha & 0,7 & 140,0 ha & 0,3 & 12,5 ha & $-4,3$ ha \\
\hline 0,9 & 100 ha & 0,1 & 75 ha & 0,7 & 145,0 ha & 0,3 & 12,5 ha & $-7,8$ ha \\
\hline 0,9 & 100 ha & 0,1 & 75 ha & 0,7 & 150,0 ha & 0,3 & 12,5 ha & $-11,3$ ha \\
\hline 0,9 & 100 ha & 0,1 & 75 ha & 0,7 & 155,0 ha & 0,3 & 12,5 ha & $-14,8$ ha \\
\hline 0,9 & 100 ha & 0,1 & 75 ha & 0,7 & 162,5 ha & 0,3 & 12,5 ha & $-20,0$ ha \\
\hline 0,9 & 100 ha & 0,1 & 75 ha & 0,7 & 170,0 ha & 0,3 & 12,5 ha & $-25,3$ ha \\
\hline 0,9 & 100 ha & 0,1 & 75 ha & 0,7 & 180,0 ha & 0,3 & 12,5 ha & $-32,3$ ha \\
\hline 0,9 & 100 ha & 0,1 & 75 ha & 0,7 & 192,5 ha & 0,3 & 12,5 ha & $-41,0$ ha \\
\hline 0,9 & 100 ha & 0,1 & 75 ha & 0,7 & 207,5 ha & 0,3 & 12,5 ha & $-51,5 \mathrm{ha}$ \\
\hline 0,9 & 100 ha & 0,1 & 75 ha & 0,7 & 225,0 ha & 0,3 & 12,5 ha & $-63,8$ ha \\
\hline 0,9 & 100 ha & 0,1 & 75 ha & 0,7 & 250,0 ha & 0,3 & 12,5 ha & $-81,3 \mathrm{ha}$ \\
\hline 0,9 & 100 ha & 0,1 & 75 ha & 0,7 & 275,0 ha & 0,3 & 12,5 ha & $-98,8$ ha \\
\hline 0,9 & 100 ha & 0,1 & 75 ha & 0,7 & 325,0 ha & 0,3 & 12,5 ha & $-133,8$ ha \\
\hline
\end{tabular}




\begin{tabular}{|c|c|c|c|c|c|c|c|c|}
\hline \multicolumn{9}{|c|}{ Series 3} \\
\hline \multicolumn{4}{|c|}{ Program A } & \multicolumn{4}{|c|}{ Program B } & \multirow{2}{*}{$\begin{array}{l}\text { EV(A)- } \\
\text { EV(B) }\end{array}$} \\
\hline Prob. & $\begin{array}{l}\text { Saved } \\
\text { forest }\end{array}$ & Prob. & $\begin{array}{l}\text { Burned } \\
\text { forest }\end{array}$ & Prob. & $\begin{array}{l}\text { Saved } \\
\text { forest }\end{array}$ & Prob. & $\begin{array}{l}\text { Burned } \\
\text { forest }\end{array}$ & \\
\hline 0,5 & 62,5 ha & 0,5 & $10 \mathrm{ha}$ & 0,5 & 75 ha & 0,5 & 52,5 ha & 15,0 ha \\
\hline 0,5 & 10,0 ha & 0,5 & 10 ha & 0,5 & 75 ha & 0,5 & 52,5 ha & $-11,3$ ha \\
\hline 0,5 & 2,5 ha & 0,5 & 10 ha & 0,5 & 75 ha & 0,5 & 52,5 ha & $-15,0$ ha \\
\hline 0,5 & $2,5 \mathrm{ha}$ & 0,5 & 10 ha & 0,5 & 75 ha & 0,5 & 40,0 ha & $-21,3$ ha \\
\hline 0,5 & $2,5 \mathrm{ha}$ & 0,5 & 20 ha & 0,5 & 75 ha & 0,5 & 40,0 ha & $-26,3$ ha \\
\hline 0,5 & 2,5 ha & 0,5 & 20 ha & 0,5 & 75 ha & 0,5 & 35,0 ha & $-28,8$ ha \\
\hline 0,5 & 2,5 ha & 0,5 & 20 ha & 0,5 & 75 ha & 0,5 & 27,5 ha & $-32,5$ ha \\
\hline
\end{tabular}

In series 3 respondents were told that each program, when completed, could end in either success or failure. In the latter case, more forests will be burned than would be the case under the current management regime. 5 Payoffs from the environmental lotteries in Series 3 were presented therefore as either the additional forest area saved from burning or as an increase in the area of forest burned relative to the current area damaged by wildfires. Similarly to Riddel (2012), respondents' choices were not incentivized in either domain to allow full comparability, i.e. choices in both domains were hypothetical.

\subsection{Risk taking propensity measure}

We adopted the 30 item version of the DOSPERT scale from Blais and Weber (2006) (see Table 3). This is a psychometric scale that assesses risk taking in five content domains: financial, health/safety, recreational, ethical, and social. In this approach respondents are asked to rate the likelihood of engagement in domain-specific risky activities using a 7-point rating scale ranging from 1 - "extremely unlikely" to 7 "extremely likely". Then the activity-specific risk-talking propensity scores are aggregated into domain-specific risk-taking propensity score.

\footnotetext{
${ }^{5}$ At the beginning of the survey the risk of forest wildfires in Poland, their effects, risk factors and the possible methods to reduce this risk were described to respondents based on historical data.
} 
Table 4. Domain-Specific Risk-Taking (DOSPERT) items.

\begin{tabular}{|c|c|}
\hline Financial & Health/safety \\
\hline 1. Betting a day's income at the horse races. & 1. Drinking heavily at a social function. \\
\hline 2. Investing $10 \%$ of your annual income in a & 2. Engaging in unprotected sex. \\
\hline moderate growth mutual fund. & 3. Driving a car without wearing a seat belt. \\
\hline $\begin{array}{l}\text { 3. Betting a day's income at a high-stake poker } \\
\text { game. }\end{array}$ & $\begin{array}{l}\text { 4. Riding a motorcycle without a helmet. } \\
\text { 5. Sunbathing without sunscreen. }\end{array}$ \\
\hline $\begin{array}{l}\text { 4. Investing } 5 \% \text { of your annual income in a very } \\
\text { speculative stock. }\end{array}$ & $\begin{array}{l}\text { 6. Walking home alone at night in an unsafe area } \\
\text { of town. }\end{array}$ \\
\hline $\begin{array}{l}\text { 5. Betting a day's income on the outcome of a } \\
\text { sporting event }\end{array}$ & \\
\hline $\begin{array}{l}\text { 6. Investing } 10 \% \text { of your annual income in a new } \\
\text { business venture. }\end{array}$ & \\
\hline
\end{tabular}

\section{Recreational}

1. Going camping in the wilderness.

2. Going down a ski run that is beyond your ability.

3. Going whitewater rafting at high water in the spring.

4. Taking a skydiving class.

5. Bungee jumping off a tall bridge.

6. Piloting a small plane.

\section{Ethical}

1. Taking some questionable deductions on your income tax return.

2. Having an affair with a married man/woman.

3. Passing off somebody else's work as your own.

4. Revealing a friend's secret to someone else.

5. Leaving your young children alone at home while running an errand.

6. Not returning a wallet you found that contains $1000 \mathrm{zł}$.

\section{Social}

1. Admitting that your tastes are different from those of a friend.

2. Disagreeing with an authority figure on a major issue.

3. Choosing a career that you truly enjoy over a more secure one.

4. Speaking your mind about an unpopular issue in a meeting at work.

5. Moving to a city far away from your extended family.

6. Starting a new career in your mid-thirties.

Note: responses were recorded on a 7-point rating scale ranging from 1 - "extremely unlikely" to 7 "extremely likely".

\section{The Survey}

Interviews were conducted face-to-face with members of the public by a professional polling agency in five cities in Polandin August and September 2013. ${ }^{6}$ A quota sampling was applied representative of the Polish population in terms of age and gender. In total, 630 interviews were conducted. All respondents participated both in financial and in environmental experiments. ${ }^{7}$ Among them, 34 made multiple switches

\footnotetext{
${ }^{6}$ Gdańsk, Łódź, Katowice, Poznań, and Warsaw.

${ }^{7}$ Due to limited space we focus on the results and do not describe the survey in detail here. The survey is available on request from the communicating author.
} 
in the lottery tasks and were therefore excluded from the further analysis. Table 4 reports basic socio-demographics and the responses to a question asking respondents how important they think it is to manage the risk of wildfires in Poland.

Table 5. Descriptive statistics of the sample and their attitudes toward forest fires.

\begin{tabular}{|c|c|c|c|c|c|}
\hline & $\%$ & Mean & Median & Min & Max \\
\hline Women & 56.67 & & & & \\
\hline Age & & 39 & 37 & 18 & 64 \\
\hline \multicolumn{6}{|l|}{ Education } \\
\hline - Primary & 0.63 & & & & \\
\hline - Secondary & 58.42 & & & & \\
\hline - High & 40.95 & & & & \\
\hline Net monthly individual income in zł & & & $3001-4000$ & $0-1000$ & $\begin{array}{l}10001- \\
20000\end{array}$ \\
\hline \multicolumn{6}{|l|}{ Wildfires in Poland are a: } \\
\hline - Definitely important issue & 49.21 & & & & \\
\hline - $\quad$ Rather important issue & 41.59 & & & & \\
\hline - $\quad$ Neither/nor & 7.62 & & & & \\
\hline - $\quad$ Rather unimportant issue & 1.43 & & & & \\
\hline - Definitely unimportant issue & 0.16 & & & & \\
\hline
\end{tabular}

\section{Results}

\subsection{Lottery choices - values of parameters}

If both the probability sensitivity parameter $\alpha=1$ and the loss aversion parameter $\lambda=1$, then the assumed value function would reduce to the standard EU function. Responses to both Series 1 and 2 jointly determine $\alpha$. Figure 1 shows the distribution of the switching points for the two first series of financial lotteries. Next, Figure 2 gives the corresponding distribution for the environmental lotteries. 


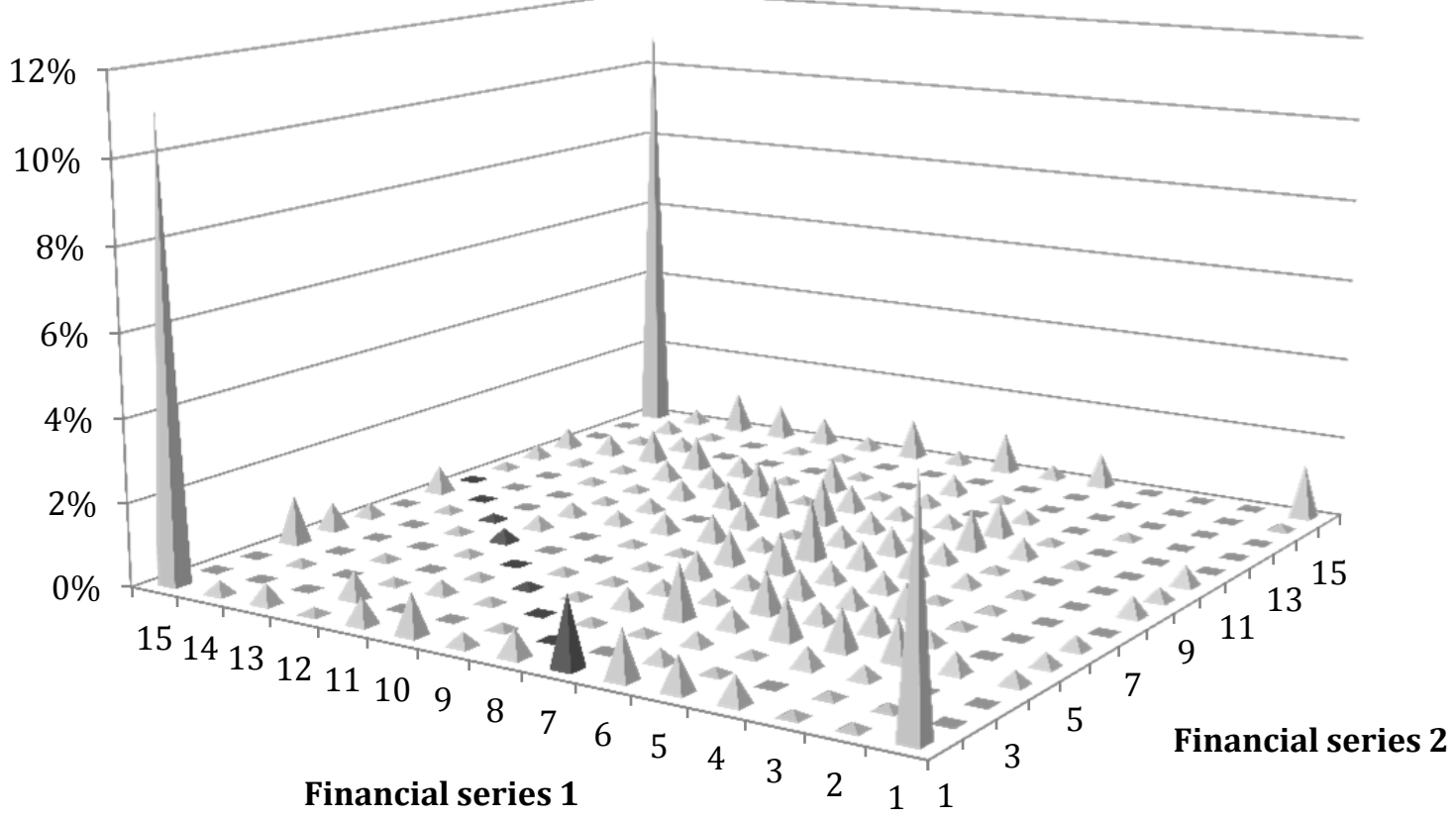

Figure 1. Switching points for financial choices in Series 1 and 2

Note: Black represent the choices consistent with EUT assuming constant relative risk aversion with utility function $\mathrm{u}(\mathrm{x})=\mathrm{x}^{1-\sigma} / 1-\sigma$, i.e. switching points combinations for Series 1 and Series 2: $(7,1),(8,2)$, $(9,3),(10,4),(11,5),(12,6),(13,7),(14,8)$ and $(15$-never switch, 9).

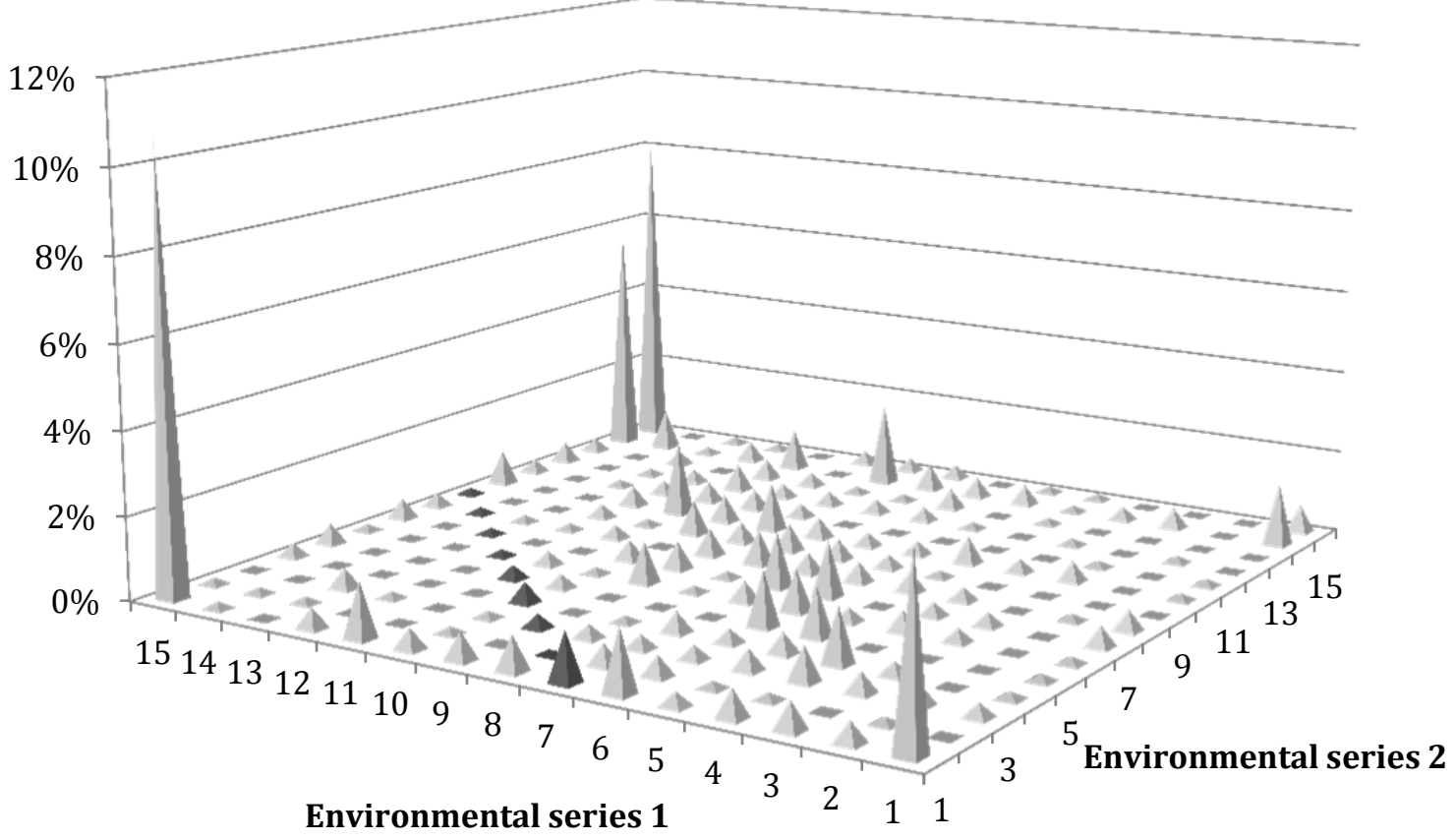

Figure 2. Switching points for environmental choices in Series 1 and 2 Note: Black represent the choices consistent with EUT. 
In both cases there was no obvious tendency for respondents to cluster around the middle choice of the lotteries series. Results from the financial lotteries suggest that only $2 \%$ of respondents made choices consistent with EUT. In the case of the environmental lotteries this share equaled 3\%.

The average derived value of the probability weighting parameter $\alpha$ was significantly different from one at the $1 \%$ significance level by t-test, rejecting EU in favor of inverted-S shaped probability weighting in both financial and environmental domain. Table 6 presents the statistics for $\alpha$. The similar results were obtained by Riddel (2012). However, in her study the probability weighting parameter for the environmental risk was lower than that for financial risk. In our study, based on results from a paired t-test (null hypothesis $\left.\bar{\alpha}_{E}=\bar{\alpha}_{F}\right)^{8}$, we cannot reject the hypothesis that both estimated means are equal ( $\mathrm{p}$-value $=0.8683,95 \%$ confidence level). The results of the equality of means test suggest that the probability weighting functions in both environmental and financial domains are similar, meaning that respondents weighed the likelihood of extreme outcomes equally across the two domains ${ }^{9}$.

Table 6. Probability sensitivity parameters in Prelec's weighting function $(\alpha)$ in the environmental and the financial domain.

\begin{tabular}{lcccc}
\hline & Mean & Std. Dev. & Minimum & Maximum \\
\hline$\alpha_{\mathrm{F}}$ & 0.770 & 0.329 & 0.05 & 1.45 \\
$\alpha_{\mathrm{E}}$ & 0.773 & 0.324 & 0.05 & 1.45 \\
\hline
\end{tabular}

The loss aversion parameter $\lambda$ is determined by the switching point in Series 3 and by value of parameter $\sigma$ (the curvature of the value function) obtained from individuals choices in Series 1 and Series. Figure 3 shows the distribution of switching points for Series 3 of financial and environmental lotteries.

\footnotetext{
8 The subscripts $\mathrm{E}$ and $\mathrm{F}$ are for environmental domain and financial domain, respectively.

9 The results of Mann-Whitney test suggest that there is not a statistically significant difference between the underlying distributions of the probability weighting parameter in the financial and environmental domains $(\mathrm{z}=1.201$, $\mathrm{p}$-value $=0.2298)$
} 


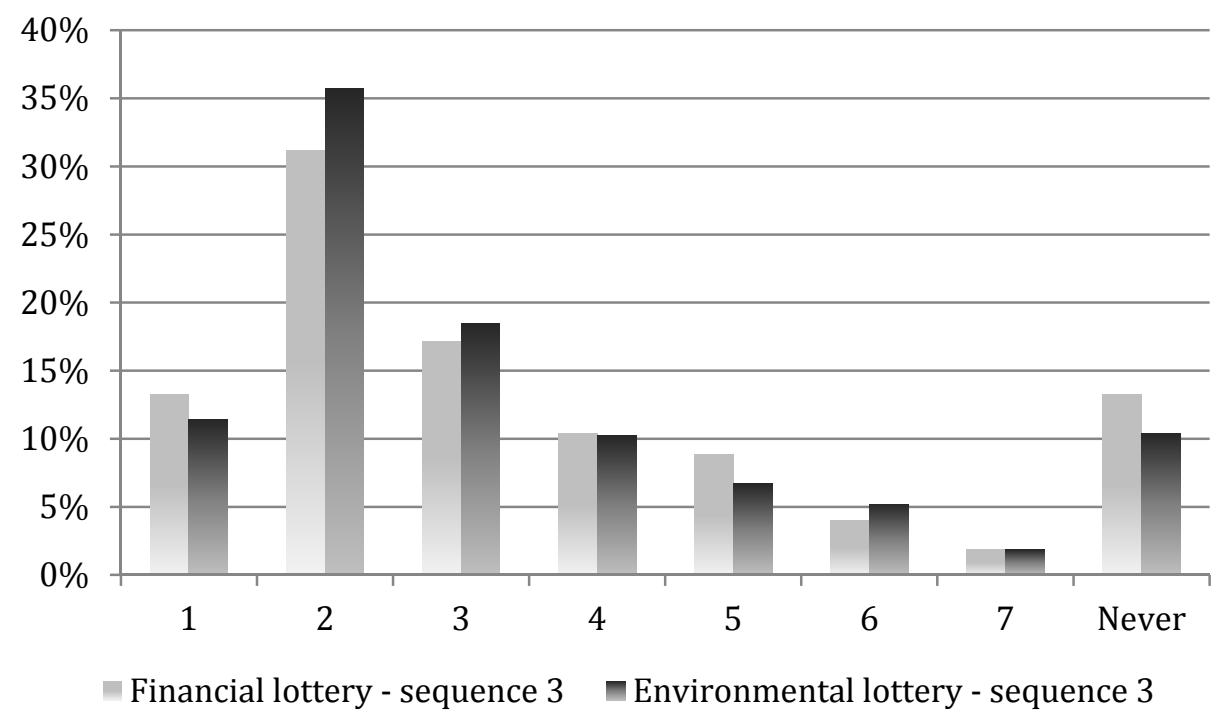

Figure 3. Distribution of switch-points between Lottery A to B

The share of individuals with $\lambda$ in the interval 0.9-1.1 (consistent with the EUT) in the financial and the environmental lotteries was equal $4 \%$ and $5 \%$, respectively. The average estimated value of the loss aversion parameter in the financial series of lotteries was 3.010, whereas for environmental series this value was equal to 3.019.10 The results of the paired t-test suggest that the estimated values are equal (the null hypothesis $\bar{\lambda}_{\mathrm{E}}=\bar{\lambda}_{\mathrm{F}}, \mathrm{p}$-value $=0.2993,95 \%$ confidence level). ${ }^{11}$ The average estimated value of loss aversion in both cases is also significantly different from 1 at $1 \%$ level by t-test indicating choices are not consistent with the EUT.12

Table 7. Loss aversion parameter $(\lambda)$ in the environmental and the financial domain.

\begin{tabular}{lcccc}
\hline & Mean & Std. Dev. & Minimum & Maximum \\
\hline$\lambda_{\mathrm{F}}$ & 3.010 & 3.934 & 0.116 & 13.394 \\
$\lambda_{\mathrm{E}}$ & 3.019 & 3.916 & 0.116 & 13.394 \\
\hline
\end{tabular}

\subsection{Risk taking attitudes}

Table 7 reports the mean DOSPERT scores. The mean risk-taking level varied between domains with the largest mean in the social area (26.66) and the smallest mean in the ethical domain (11.94). The internal consistency estimates for the risk-taking scores (i.e. Cronbach's alpha) range from 0.60 to 0.83 .

10 Following Liu (2013) we assigned the maximum value of $\lambda$ at 15 instead of infinity.

11 The results of Mann-Whitney test confirm that there is not a statistically significant difference between the underlying distributions of the loss aversion parameter in the financial and environmental domains $(\mathrm{z}$ $=-0.094, \mathrm{p}$-value $=0.9248$ ) 
Table 8. Domain-Specific Risk-Taking (DOSPERT) Scale.

\begin{tabular}{|c|c|c|c|c|c|}
\hline $\begin{array}{l}\text { DOSPERT score - risk } \\
\text { taking }\end{array}$ & Mean & Std. Dev. & Minimum & Maximum & $\begin{array}{c}\text { Cronbach's } \\
\text { alpha }\end{array}$ \\
\hline 1. Ethical & 11.94 & 5.02 & 6 & 36 & 0.60 \\
\hline 2. Financial & 13.64 & 7.40 & 6 & 42 & 0.83 \\
\hline 3. Health/Safety & 17.36 & 6.71 & 6 & 38 & 0.64 \\
\hline 4. Recreational & 16.80 & 8.80 & 6 & 42 & 0.83 \\
\hline 5. Social & 26.66 & 7.18 & 6 & 42 & 0.71 \\
\hline
\end{tabular}

Based on DOSPERT results we created five DOSPERT indices one for each domain. They were used later on to check if the likelihood of engaging in risky activities relating to different domains affects PT parameters obtained from financial and environmental lottery choice tasks.

\subsection{Drivers of domain specificity for probability weighting and loss aversion}

The estimated means of the probability weighting parameters and the means of loss aversion parameters for financial and environmental are not significantly different according to the results of a basic test of equality of means. However, there may still be inherent domain-specific preferences caused by other types of heterogeneity within the population. To investigate this we run two regression models where the probability weighting parameter and the loss aversion parameter are functions of domain indicators, behavioral (five DOSPERT risk-talking indexes) and demographic variables. First, we model the nonlinear probability weighting parameter. In this case, we applied the censored logistic model with censoring outside the range 0.05-1.45 (the lowest and the highest value of $\alpha$ ). Table 6 displays the estimation results. 
Table 9. Results of the censored logistic models for probability weights

\begin{tabular}{|c|c|c|c|}
\hline \multicolumn{2}{|c|}{ Model I } & \multicolumn{2}{|c|}{ Model II } \\
\hline Parameter & Coefficient & Parameter & Coefficient \\
\hline Age*F & $\begin{array}{l}0.0001 \\
(0.0009)\end{array}$ & \multirow{2}{*}{ Age } & \multirow{2}{*}{$\begin{array}{l}-0.0001 \\
(0.0008)\end{array}$} \\
\hline Age*E & $\begin{array}{l}-0.0003 \\
(0.0009)\end{array}$ & & \\
\hline Gender*F & $\begin{array}{c}0.0018 \\
(0.0269)\end{array}$ & \multirow{2}{*}{ Gender } & \multirow{2}{*}{$\begin{array}{l}-0.0010 \\
(0.0194)\end{array}$} \\
\hline Gender*E & $\begin{array}{l}-0.0036 \\
(0.0265)\end{array}$ & & \\
\hline Higher education*F & $\begin{array}{c}-0.0452^{*} \\
(0.0266)\end{array}$ & Higher education & $\begin{array}{l}-0.0465 * \\
(0.0250)\end{array}$ \\
\hline Higher education*E & $\begin{array}{l}-0.0308 \\
(0.0040)\end{array}$ & Higher education & $\begin{array}{l}-0.0289 \\
(0.0249)\end{array}$ \\
\hline Income(in 1000zł)*F & $\begin{array}{l}-0.0046 \\
(0.0044)\end{array}$ & \multirow{2}{*}{ Income(in 1000zł) } & \multirow{2}{*}{$\begin{array}{l}-0.0038 \\
(0.0030)\end{array}$} \\
\hline Income(in 1000zł)*E & $\begin{array}{l}-0.0029 \\
(0.0008)\end{array}$ & & \\
\hline DOSPERT_eth.*F & $\begin{array}{l}0.0085^{* * *} \\
(0.0031)\end{array}$ & DOSPERT_eth. & $\begin{array}{l}0.0088^{* * *} \\
(0.0030)\end{array}$ \\
\hline DOSPERT_eth.*E & $\begin{array}{l}0.0034 \\
(0.0030)\end{array}$ & DOSPERT_eth. & $\begin{array}{l}0.0031 \\
(0.0030)\end{array}$ \\
\hline DOSPERT_fin.*F & $\begin{array}{c}-0.0045^{*} \\
(0.0023)\end{array}$ & \multirow{2}{*}{ DOSPERT_fin. } & \multirow{2}{*}{$\begin{array}{l}-0.0053^{* * *} \\
(0.0016)\end{array}$} \\
\hline DOSPERT_fin.*E & $\begin{array}{l}-0.0061^{* * *} \\
(0.0023)\end{array}$ & & \\
\hline DOSPERT_health.*F & $\begin{array}{c}-0.0044 * \\
(0.0026)\end{array}$ & DOSPERT_health. & $\begin{array}{c}-0.0041^{*} \\
(0.0023)\end{array}$ \\
\hline DOSPERT_health*E & $\begin{array}{l}-0.0002 \\
(0.0026)\end{array}$ & DOSPERT_health & $\begin{array}{l}-0.0006 \\
(0.0023)\end{array}$ \\
\hline DOSPERT_rec.*F & $\begin{array}{l}0.0016 \\
(0.0021)\end{array}$ & \multirow{2}{*}{ DOSPERT_rec. } & \multirow{2}{*}{$\begin{array}{l}0.0005 \\
(0.0015)\end{array}$} \\
\hline DOSPERT_rec.*E & $\begin{array}{l}-0.0007 \\
(0.0021)\end{array}$ & & \\
\hline DOSPERT_sport*F & $\begin{array}{c}0.0008 \\
(0.0019)\end{array}$ & \multirow{2}{*}{ DOSPERT_sport. } & \multirow{2}{*}{$\begin{array}{l}0.0017 \\
(0.0014)\end{array}$} \\
\hline DOSPERT_sport.*E & $\begin{array}{l}0.0026 \\
(0.0019)\end{array}$ & & \\
\hline Constant & $\begin{array}{l}0.7710^{* * *} \\
(0.0488)\end{array}$ & Constant & \multirow[t]{2}{*}{$\begin{array}{l}0.7705^{* * *} \\
(0.0488)\end{array}$} \\
\hline Scale & $\begin{array}{l}0.1776^{* * *} \\
(0.0045)\end{array}$ & Scale & \\
\hline AIC & 680.05 & AIC & 669.45 \\
\hline BIC & 780.01 & $\mathrm{BIC}$ & 739.57 \\
\hline $\begin{array}{l}\text { Log likelihood } \\
\mathrm{N}\end{array}$ & -319.65 & $\begin{array}{l}\text { Log likelihood } \\
1136\end{array}$ & -320.54 \\
\hline
\end{tabular}

Note: ${ }^{* * *}, *$ indicates significance at 1 and $10 \%$ levels, respectively. Standard errors are reported in parentheses. The number of respondents was reduced to 568 due to missing information on income. 
The dependent variable is the probability weighting parameter $\alpha$ for financial and environmental risks. Both samples were pooled here and thus the number of observations is twice the number of respondents. The explanatory variables are interaction effects of demographics and risk talking behaviour obtained from the DOSPERT scale with two dummy variables $\mathrm{F}$ and $\mathrm{E}$ indicating whether the dependent variable was observed in the financial or environmental domain. We estimated two models: the first one with the full set of domain interaction effects and the second where we drop the interaction terms for variables which were not significant in the first model. A likelihood-ratio test indicated that Model II better fits the data.

The results of Model II suggest that none of the demographic variables are significant apart from higher education. The coefficient of the interaction effect of higher education with the financial domain is negative and significant, indicating that more educated people tend to have more pronounced curvature in their financial probability weighting function than less educated people. Additionally, the obtained results suggest that the coefficients for ethical and health/safety risk taking behaviour vary with the domains presented in the lottery tasks. More risk taking people in the ethical and health/sports risk domains show more probability weighting in the financial than in the environmental domain. However, individuals characterized by higher risk attitudes in the ethical domain have less pronounced curvature in their financial probability weighting function than people with lower risk attitudes, but people who are more risk seeking in the health/sport domain reveal more pronounced curvature in their financial probability weighting function than more risk averse people. The results also indicate that people who reveal higher risk attitudes in the financial domain in the DOSPRERT scale exhibit significant probability weighting in the financial and the environmental domains. They also have a more pronounced curvature in their probability weighting functions (both in financial and environmental domains) than people who reveal lower financial risk attitudes based on the results from the DOSPERT scale.

Next, the loss aversion parameter was modelled using OLS regression. As in the previous models, the sample was pooled to generate the dependent variables for financial and environmental risk. 
Table 10. Results of OLS regression of individual loss aversion $(\lambda)$.

\begin{tabular}{|c|c|}
\hline Parameter & Coefficient \\
\hline Age*F & $\begin{array}{l}0.0449 * * * \\
(0.0087)\end{array}$ \\
\hline Age*E & $\begin{array}{c}-0.0147^{*} \\
(0.0087)\end{array}$ \\
\hline Gender*F & $\begin{array}{c}0.0225 \\
(0.2408)\end{array}$ \\
\hline Gender*E & $\begin{array}{l}-0.1849 \\
(0.2408)\end{array}$ \\
\hline Higher education*F & $\begin{array}{c}0.2831 \\
(0.2388)\end{array}$ \\
\hline Higher education*E & $\begin{array}{l}-0.0552 \\
(0.0367)\end{array}$ \\
\hline Income (in $1000 \mathrm{zt}) * \mathrm{~F}$ & $\begin{array}{l}0.0891^{* *} \\
(0.0367)\end{array}$ \\
\hline Income(in 1000zł)*E & $\begin{array}{c}0.0232 \\
(0.0367)\end{array}$ \\
\hline DOSPERT_eth.*F & $\begin{array}{l}-0.0536^{*} \\
(0.0275)\end{array}$ \\
\hline DOSPERT_eth.*E & $\begin{array}{l}-0.0172 \\
(0.0275)\end{array}$ \\
\hline DOSPERT_fin. ${ }^{*} \mathbf{F}$ & $\begin{array}{l}-0.0862^{* * *} \\
(0.0209)\end{array}$ \\
\hline DOSPERT_fin.*E & $\begin{array}{r}0.0035 \\
(0.0209)\end{array}$ \\
\hline DOSPERT_health.*F & $\begin{array}{l}0.0538^{* *} \\
(0.0229)\end{array}$ \\
\hline DOSPERT_health*E & $\begin{array}{l}-0.0088 \\
(0.0229)\end{array}$ \\
\hline DOSPERT_rec. ${ }^{*} \mathbf{F}$ & $\begin{array}{l}0.03562^{*} \\
(0.0184)\end{array}$ \\
\hline DOSPERT_rec.*E & $\begin{array}{l}-0.0033 \\
(0.0184)\end{array}$ \\
\hline DOSPERT_sport*F & $\begin{array}{l}-0.0286^{*} \\
(0.0173)\end{array}$ \\
\hline DOSPERT_sport.*E & $\begin{array}{c}-0.0199 \\
(0.0173)\end{array}$ \\
\hline Constant & $\begin{array}{r}1.7393 \\
(0.5116) \\
\end{array}$ \\
\hline R-squared & 0.2574 \\
\hline Adj R-squared $=0.2454$ & 0.2454 \\
\hline $\mathrm{N}$ & 1136 \\
\hline
\end{tabular}

Note: $* * *, * *, *$ indicates significance at 1, 5 and 10\% levels, respectively. Standard errors are reported in parentheses. The number of respondents was reduced to 568 as not everybody declared her/his income.

Examining Table 7, we see that a higher loss aversion parameter in the financial lotteries is associated with higher age. In contrast, in the environmental lotteries loss aversion is decreasing with age. Individuals with higher income exhibit higher loss 
aversion in the financial domain. Turning to the DOSPERT interactions, they are all significant for the financial lotteries but not for the environmental lotteries. A higher DOSPERT financial, social and ethical index (i.e. higher risk taking) decreases the degree of loss aversion. Finally, the higher recreational and health/safety index increases the degree of loss aversion, possibly as a result of experience (in losing).

\section{Discussion and Conclusions}

Recent studies as the one by Riddle (2012) show that the assumption that EU models characterise preferences over stochastic environmental gains well is in many cases not justified. In contrast, subjects seem to place more emphasis on low probability environmental gains than one would find for the EU. The fact that probability weighting

has been found to be an important component of environmental preference functions suggests that the assumption that environmental preferences can be modelled using EU or subjective EU (see for example, Riddel and Shaw (2006), Cameron (2005) or Alberini et al. (2007)) should be modified, particularly when estimating willingness to pay (WTP) for environmental-risk reductions.

The present study has extended this analysis to account for the potential influence of loss aversion. We find that it also significantly impacts preferences. Our results show that most respondents exhibited significant probability weighting in both the environmental and financial lottery choice tasks. In contrast to Riddel's (2012) findings, however, we do not observe more a pronounced curvature in the environmental weighting function than that in the financial domain. Nevertheless, our estimates for the probability weighting parameters $\left(\alpha_{F}=\alpha_{E}=0.77\right)$ are very close to those obtained by Riddel $\left(\alpha_{\mathrm{F}}=0.77, \alpha_{\mathrm{E}}=0.70\right)$.

.Further, our results also indicate that loss aversion also does not appear to be domain-specific. However, the average estimated value of loss aversion in both cases was significantly different from one supporting the thesis that respondents' choices were not consistent with EUT. In this study, the loss aversion parameters were estimated at 3.01 and 3.02 for the financial end environmental domains respectively. Tanaka et al. (2010) report a value for the loss aversion parameter of 2.63 for Vietnamese households, and Liu (2013) a value of 3.47 for Chinese farmers. However, Novemsky and Kahneman (2005) present slightly lower values of the loss aversion coefficients in financial context from studies in developed countries. In this case, a value of about 2 was reported for the loss aversion parameter.

In the survey we included the self-reported Domain-Specific Risk-Taking (DOSPERT) scale. The stated risk talking behavior appeared to be a significant explanatory variable both in the case of the probability weighting and the loss aversion parameters, but had different effects, suggesting domain specificity may arise in respect of the drivers of these parameters.

Overall, our results indicate that assuming EUT underpins respondent choices in stated preference surveys involving risky environmental goods may be misplaced. Given that both probability weighting and loss aversion occur, it is reasonable to conclude that prospect theory is indeed a better behavioural descriptor. However, the degree to which preference measures such as stated WTP estimates may be biased is an empirical question and our data are not sufficient to resolve this issue. Thus, in future studies it would be useful to collect additional data on respondent risk preferences and loss aversion as well as individual WTP in order to generate a body of data to address 
directly the question of how large (or small) such a bias might be . In addition, further research is merited in order to better understand the apparently different interactions between loss aversion and risk attitudes in the financial and environmental domains. 


\section{References:}

Alberini, A., Tonin, S., Turvani, M., Chiabai, A. 2007. Paying for permanence: Public preferences for contaminated site cleanup. Journal of Risk and Uncertainty 34, 155-178.

Binswanger, H. P. 1980. Attitudes toward Risk: Experimental Measurement in Rural India. American Journal of Agricultural Economics, 62(3), 395-407.

Blais, A-R., Weber E. U. 2006. A Domain-specific Risk-taking (DOSPERT) Scale for Adult Populations. Judgment and Decision Making, 1, 33-47.

Cameron, T. A. 2005. Individual option prices for climate change mitigation. Journal of Public Economics 89, 283-301

Holt, C.A., Laury, S.K., 2002. Risk aversion and incentive effects. American Economic Review 92(5), 1644-1655.

Hanoch, Y., Johnson, J., Wilke, A. 2006. Domain specificity in experimental measures and participant recruitment an application to risk-taking behavior. Psychological Science, 17, 300-304.

Kahneman, T., A., Tversky, A. 1979. Prospect Theory: An analysis of decision under risk. Econometrica 47 (2), 263-291.

Liu, E. M. 2013. Time to Change What to Sow: Risk Preferences and Technology Adoption Decisions of Cotton Farmers in China. The Review of Economics and Statistics, 95(4), 1386-1403.

Novemsky, N., Kahneman, D. 2005. The Boundaries of Loss Aversion. Journal of Marketing Research 42, 119-128.

Prelec, D. 1998. The Probability Weighting Function. Econometrica, 66(3), 497-527.

Riddel, M. 2012. Comparing risk preferences over financial and environmental lotteries. Journal of Risk and Uncertainty, 45, 135-157.

Riddel, M., Shaw, W. D. 2006. A theoretically-consistent empirical model of non-expected utility: An application to nuclear-waste transport. Journal of Risk and Uncertainty, $32,131-150$

Starmer, C. 2000. Developments in non-expected utility theory: The hunt for a descriptive theory of choice under risk. Journal of Economic Literature, 38, 332382.Tanaka, T., Camerer, C., Nguyen, Q. 2010. Risk and time preferences: Linking experimental and household survey data from Vietnam. American Economic Review, 100(1): 557-571.

Tversky, A., Kahneman, T., A. 1992. Advances in Prospect Theory: Cumulative Representation of Uncertainty. Journal of Risk \& Uncertainty, 5(4), 297-323.

Weber, E. U., Blais, A. R., Betz, N. E. 2002. A domain-specific risk-attitude scale: Measuring risk perceptions and risk behaviors. Journal of Behavioral Decision Making, 15, 263-290.

Weber, E.U., Johnson, E.J., 2008. Decisions under uncertainty: psychological, eco-nomic and neuroeconomic explanations of risk preference. In: Glimcher, P.,Camerer, C., Fehr, E., Poldrack, R. (Eds.), Neuroeconomics: Decision Making and the Brain. Elsevier Science, New York, pp. 127-144. 


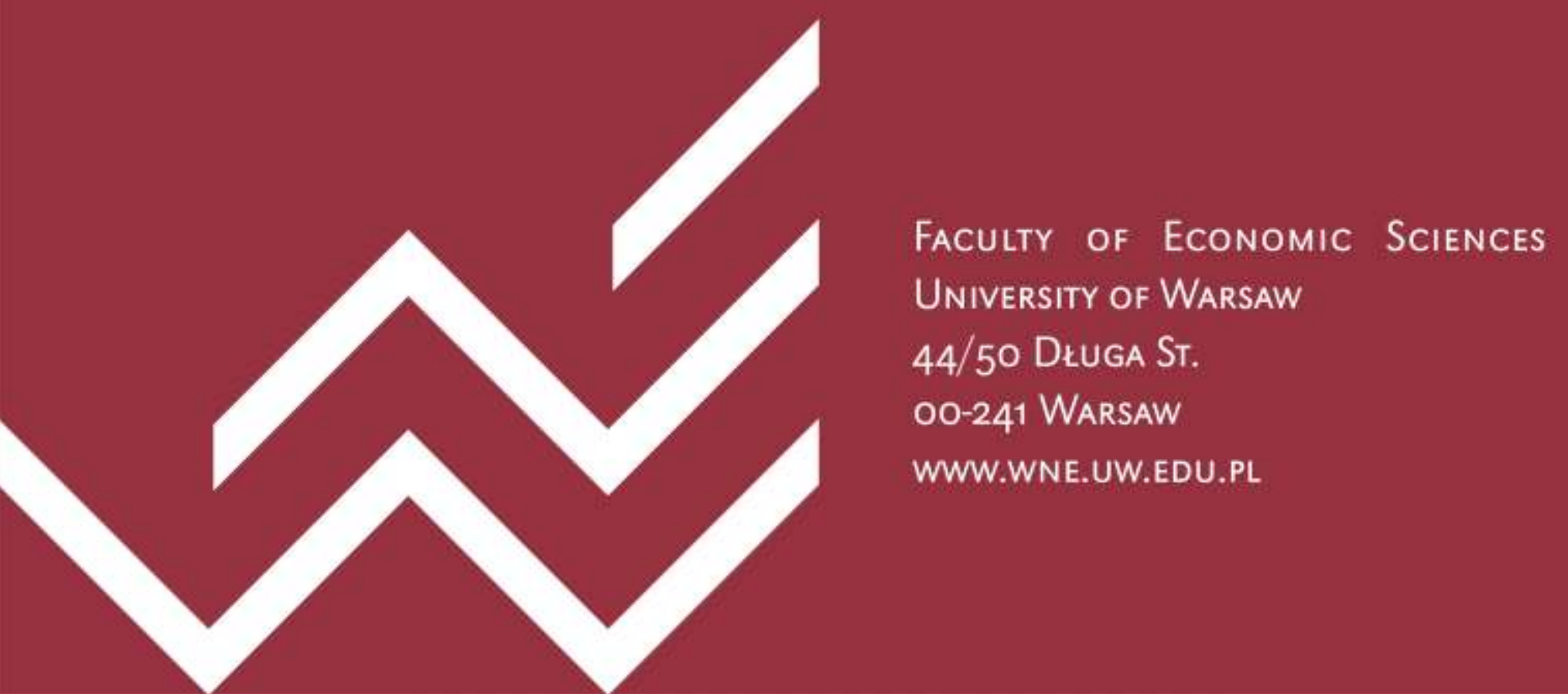

